\title{
Timbulan dan Komposisi Sampah Rumah Tangga di Kecamatan Rungkut Surabaya
}

\author{
Helena Ratya dan Welly Herumurti \\ Departemen Teknik Lingkungan, Fakultas Teknik Sipil dan Perencanaan, Institut Teknologi \\ Sepuluh Nopember (ITS) \\ e-mail: herumurti@enviro.its.ac.id
}

\begin{abstract}
Abstrak-Kecamatan Rungkut dengan kepadatan penduduk sebesar 2.477 jiwa $/ \mathbf{k m}^{2}$ masih memiliki permasalahan dalam penanganan sampah. Terjadi peningkatan jumlah sampah rumah tangga per hari yang dihasilkan seiring dengan bertambahnya jumlah penduduk. Angka laju timbulan dan komposisi serta densitas sampah rumah tangga belum diketahui secara pasti. Tujuan dari penelitian ini adalah menentukan timbulan, komposisi, densitas sampah kawasan perumahan, rumah susun, dan perkampungan. Pengukuran timbulan sampah sebanyak 8 buah sampel menggunakan metode load count analysis. Komposisi dan densitas sampah ditentukan dan dianalisis menggunakan metode yang sesuai dengan SNI 19-39641994. Timbulan sampah rumah tangga kawasan perumahan, rumah susun, dan perkampungan yaitu masing-masing sebesar 0,271 kg/orang.hari, 0,282 kg/orang.hari, dan 0,486 kg/orang.hari. Sampah perumahan, rumah susun, dan perkampungan memiliki komposisi paling banyak adalah sampah dapat dikomposkan. Hal ini dikarenakan banyaknya kegiatan rumah tangga sehingga menimbulkan banyaknya sampah dapur atau sisa makanan. Sampah plastik dan kertas merupakan jenis sampah paling banyak setelah sampah dapat dikomposkan. Sedangkan untuk densitas sampah rumah tangga di Kecamatan Rungkut sebesar $154,93 \mathrm{~kg} / \mathrm{m}^{3}$.
\end{abstract}

Kata Kunci — densitas, komposisi, timbulan.

\section{PENDAHULUAN}

$\mathrm{S}_{\mathrm{n}}^{\mathrm{A}}$ AMPAH rumah tangga (household solid waste) merupakan masalah serius di kota-kota besar dengan kepadatan penduduk yang tinggi. Surabaya, salah satu kota terbesar di Indonesia yang sangat padat juga menghadapi masalah sampah, yang penyebab utamanya adalah kurangnya lahan untuk TPA, kurangnya dana, dan kurangnya fasilitas yang disediakan [1]. Luas wilayah Surabaya seluruhnya kurang lebih $326,36 \mathrm{~km}^{2}$ yang terbagi dalam 31 Kecamatan dan 163 Desa atau Kelurahan [2]. Jumlah penduduk di sebuah daerah akan naik setiap waktu, termasuk di Kota Surabaya. Pertambahan jumlah penduduk ini akan berbanding lurus dengan bertambahnya timbulan sampah yang dihasilkan.

Kecamatan Rungkut adalah kecamatan di Surabaya Timur dengan luas wilayah 2104,18 ha dengan jumlah penduduk 110.831 jiwa [2]. Sampah di Kecamatan Rungkut terdiri dari sampah rumah tangga dan sampah sejenis sampah rumah tangga. Sampah rumah tangga adalah sampah yang berasal dari kegiatan sehari-hari dalam rumah tangga yang sebagian besar terdiri dari sampah organik, tidak termasuk tinja dan sampah spesifik [3]. Volume sampah terbesar berasal dari permukiman yang mencapai jumlah $79,19 \%$ dari total timbulan sampah [4].

Penelitian mengenai timbulan sampah rumah tangga di Kecamatan Rungkut sudah pernah dilakukan. Berdasarkan penelitian tersebut, timbulan sampah rumah tangga di Kecamatan Rungkut pada tahun 2013 sebesar 0,31 $\mathrm{kg} /$ jiwa.hari [5]. Namun angka tersebut dapat sewaktu-waktu berubah dan bertambah seiring dengan berjalannya waktu. Timbulan sampah rumah tangga di Kecamatan Rungkut belum didapatkan per kawasan permukiman. Maka dari itu perlu diketahuinya secara pasti timbulan dan karakteristik sampah rumah tangga yang berasal dari kawasan permukiman untuk dapat dilakukan pengelolaan yang sesuai. Kawasan permukiman tersebut meliputi perumahan, rumah susun, dan perkampungan atau rumah biasa.

\section{METODE PENELITIAN}

Jenis data yang digunakan untuk penelitian ini ada dua, yaitu data primer dan data sekunder. Data primer didapatkan dari pengamatan langsung ke lapangan. Pengamatan dilakukan dengan pengukuran langsung timbulan dan komposisi sampah.

Pengukuran timbulan dan densitas sampah menggunakan metode load count analysis. Metode ini merupakan metode pengukuran timbulan dengan mengukur jumlah (berat atau volume) sampah yang masuk ke TPS. Pengambilan data dilaksanakan selama 8 hari sesuai yang tercantum dalam SNI 19-3964-1994 tentang metode pengambilan dan pengukuran sampel timbulan dan komposisi sampah perkotaan [6]. Persamaan yang digunakan untuk menghitung timbulan sampah adalah sebagai berikut:

Timbulan Sampah per orang (kg/org.hari)

$$
=\frac{\text { berat sampah total ( } \mathrm{kg} / \mathrm{hari})}{\text { jumlah penduduk yang disampling (orang) }}
$$

Timbulan Sampah total per kecamatan (kg/hari) $=$ timbulan sampah per orang (kg/org.hari) $\mathrm{x}$ jumlah penduduk kecamatan

TPS yang dijadikan titik sampling pengambilan data timbulan dan komposisi sampah dipilih yang wilayah pelayanannya meliputi rumah susun, perumahan, dan perkampungan. Kedua TPS ini adalah TPS Penjaringan Sari dan TPS Wonorejo.

Data komposisi didapatkan dengan memilah sampah sebanyak $100 \mathrm{~kg}$ dan dibagi dalam jenis-jenis sampah. Jenisjenis tersebut meliputi plastik (HDPE plastik, HDPE botol, HDPE alumunium, LDPE, PET warna, PET transparan, PS 
Styrofoam, PP bag, dan lain-lain), sampah dapat dikomposkan (sisa makanan dan sampah kebun), kertas (koran, kertas HVS, duplek, tetra pack, karton, tissue, dan lain-lain), logam (besi, kaleng, kaleng cans, dan kabel/tembaga), kaca (botol kaca dan kaca lain), kain, kayu, karet, diapers (popok dan pembalut), B3, dan residu. Selain itu, komposisi sampah yang dianalisis berdasarkan hasil sampling dapat diklasifikasikan dan digambarkan melalui diagram.

Komposisi sampah $(\%)=\frac{\text { Jenis sampah }(\mathrm{kg})}{\text { Berat sampah }(100 \mathrm{~kg})} \times 100 \%$

Volume sampah diperoleh dari hasil pengukuran terhadap volume sampah pada tiap gerobak yang masuk ke TPS di Kecamatan Rungkut. Melalui data tersebut, selanjutnya dapat dihitung densitas sampah. Densitas sampah yang dihitung adalah densitas sampah di gerobak TPS.

Densitas Sampah $\left(\mathrm{kg} / \mathrm{m}^{3}\right)=\frac{\text { Berat Sampah }(\mathrm{kg})}{\text { Volume } \operatorname{sampah}\left(\mathrm{m}^{3}\right)}$

\section{HASIL DAN PEMBAHASAN}

\section{A. Timbulan dan Densitas Sampah Rumah Tangga}

Timbulan sampah per satuan penduduk didapatkan dari jumlah sampah di gerobak yang masuk TPS per jumlah sumber sampah yang dilayani oleh gerobak. Angka laju timbulan sampah dibedakan menjadi tiga, yaitu laju timbulan sampah perumahan, rumah susun, dan perkampungan. Laju timbulan sampah dari kawasan perumahan sebesar 0,271 $\mathrm{kg} /$ orang.hari. Timbulan sampah yang dihasilkan dari kawasan rusun sebesar $0,282 \mathrm{~kg} /$ orang.hari. Timbulan sampah yang dihasilkan dari kawasan rumah biasa atau perkampungan sebesar 0,486 kg/orang.hari.

Data-data timbulan sampah rumah tangga di atas merupakan data laju timbulan yang didapatkan per kawasan permukiman. Surabaya termasuk dalam kota metropolitan dengan jumlah penduduk lebih dari 2 juta penduduk. Menurut SNI-3242-2008, kota besar dan metropolitan memiliki timbulan sampah mencapai 3 L/orang.hari [7]. Apabila dikonversikan ke dalam satuan massa, yaitu dikali dengan densitas sampah hasil penelitian sebesar $154,93 \mathrm{~kg} / \mathrm{m}^{3}$, maka angka timbulan tersebut menjadi sebesar $0,465 \mathrm{~kg} /$ orang.hari. Timbulan yang telah didapatkan dari ketiga kawasan permukiman dibandingkan dengan timbulan tipikal berdasarkan SNI tersebut, maka timbulan kawasan perumahan dan rumah susun di Rungkut tergolong kecil, sedangkan timbulan perkampungan tergolong sama dengan timbulan tipikal pada SNI. Hal ini dikarenakan pada perumahan dan rumah susun, kegiatan domestik atau sampah sisa dapur tidak banyak dihasilkan dimana massa sampah sangat dipengaruhi oleh sampah sisa makanan (sampah basah) yang memiliki komposisi dan massa satuan paling besar. Pada perkampungan, masyarakat banyak berbelanja bahan makanan sendiri, dan banyak menghasilkan sampah sisa makanan yang menyebabkan besarnya laju timbulan sampah rumah tangga.

Timbulan sampah per kawasan tersebut juga dibandingkan dengan besarnya timbulan sampah rumah tangga di Kecamatan Rungkut pada penelitian sebelumnya yaitu sebesar 0,31 kg/orang.hari [5]. Angka laju timbulan sampah perumahan dan rumah susun hasil penelitian lapangan masih lebih kecil dibandingkan dengan angka tersebut. Sedangkan untuk sampah perkampungan, lebih besar dibandingkan dengan angka tersebut. Hal ini dikarenakan pada penelitian tahun 2013 tersebut, laju timbulan didapatkan dari seluruh sampah rumah tangga, tidak dilakukan per kawasan. Pada tahun 2017 atau kondisi eksisting, timbulan sampah diambil lebih rinci yaitu per kawasan permukiman sehingga terjadi perbedaan angka dari penelitian sebelumnya.

Selain data timbulan per kawasan permukiman di Kecamatan Rungkut, juga dilakukan pengambilan data timbulan per TPS di Kecamatan Rungkut melalui mapping TPS. Pada mapping TPS, data-data yang didapatkan adalah jumlah alat pengumpul yang masuk ke TPS, volume sampah yang masuk ke TPS, area pelayanan TPS, faktor kompaksi sampah, dan reduksi sampah di TPS.

Tabel 1.

Timbulan Sampah di TPS Kecamatan Rungkut

\begin{tabular}{|c|c|c|c|c|}
\hline \multirow[t]{2}{*}{ Nama TPS } & \multirow[t]{2}{*}{$\begin{array}{l}\text { Jumlah } \\
\text { Gerobak }\end{array}$} & $\begin{array}{l}\text { Volume } \\
\text { Sampah }\end{array}$ & \multirow{2}{*}{$\begin{array}{c}\text { Densitas } \\
\text { Sampah } \\
\left(\mathrm{kg} / \mathrm{m}^{3}\right)\end{array}$} & \multirow{2}{*}{$\begin{array}{c}\begin{array}{c}\text { Timbula } \\
\text { n } \\
\text { Sampah }\end{array} \\
\text { (kg/hari) }\end{array}$} \\
\hline & & ( $\mathrm{m}^{3} /$ hari $)$ & & \\
\hline $\begin{array}{l}\text { Penjaringan } \\
\text { Sari }\end{array}$ & 39 & 57,57 & \multirow{9}{*}{154,93} & 8919,05 \\
\hline Wonorejo & 24 & 28,75 & & 4454,72 \\
\hline Kendal Sari & 13 & 16,66 & & 2580,95 \\
\hline Tulus Harapan & 11 & 17,11 & & 2651,45 \\
\hline Medokan Ayu & 35 & 35,44 & & 5490,26 \\
\hline Rungkut Kidul & 40 & 40,50 & & 6274,59 \\
\hline $\begin{array}{l}\text { Rungkut } \\
\text { Alang-alang }\end{array}$ & 30 & 30,38 & & 4705,94 \\
\hline Metro & 10 & 10,13 & & 1568,65 \\
\hline $\begin{array}{l}\text { Rungkut Asri } \\
\text { Tengah }\end{array}$ & 7 & 7,09 & & 1098,05 \\
\hline TOTAL & 87 & 120,10 & & 37743,66 \\
\hline
\end{tabular}

Timbulan sampah didapatkan dari volume sampah yang masuk ke TPS dikalikan dengan densitas sampah. Densitas sampah sebesar $154,93 \mathrm{~kg} / \mathrm{m}^{3}$ didapatkan dari rata-rata densitas sampah rumah tangga di Kecamatan Rungkut melalui load count analysis seluruh gerobak. Contoh perhitungan timbulan sampah adalah timbulan sampah di TPS Penjaringan Sari sebagai berikut.

$$
\begin{aligned}
\text { Timbulan sampah } & =\text { volume sampah } x \text { densitas sampah } \\
& =57,57 \mathrm{~m}^{3} / \text { hari } x 154,93 \mathrm{~kg} / \mathrm{m}^{3} \\
& =8919,05 \mathrm{~kg} / \mathrm{hari}
\end{aligned}
$$

Densitas sampah sebesar $154,93 \mathrm{~kg} / \mathrm{m}^{3}$ didapatkan dari ratarata densitas sampah rumah tangga di Kecamatan Rungkut melalui metode yang sama yaitu load count analysis. Densitas dari perumahan perumahan sebesar $104,29 \mathrm{~kg} / \mathrm{m}^{3}$, densitas dari rumah susun sebesar 177,79, dan densitas sampah dari perkampungan sebesar 157,39. Angka densitas paling besar ada pada sampah dari rumah susun. Hal ini disebabkan oleh petugas pengumpul di rumah susun memasukkan sampah dari wadah komunal di rusun ke dalam kantong-kantong plastik untuk mempersingkat waktu pembongkaran di TPS. Kegiatan memasukkan sampah ke dalam kantong plastik ini sama dengan kegiatan kompaksi sampah yang menyebabkan densitas sampah rusun menjadi besar. 
Densitas Sampah Rumah Tangga Kawasan Permukiman di Kecamatan Rungkut

\begin{tabular}{lcc}
\hline \hline \multicolumn{1}{c}{$\begin{array}{c}\text { Sumber } \\
\text { Sampah }\end{array}$} & Densitas & $\begin{array}{c}\text { Densitas rata- } \\
\text { rata }\end{array}$ \\
\cline { 2 - 3 } & $\mathbf{( k g / \mathbf { m } ^ { \mathbf { 3 } } )}$ & $\left(\mathbf{k g} / \mathbf{m}^{\mathbf{3}}\right)$ \\
\hline Perumahan & 104,29 & \\
Rumah susun & 177,79 & 154,93 \\
Perkampungan & 157,39 & \\
\hline \hline
\end{tabular}

\section{B. Komposisi Sampah Rumah Tangga}

Komposisi sampah rumah tangga didapatkan dari memilah dan menimbang hasil pilahan sesuai dengan jenisnya kemudian dinyatakan dalam persentase (\%). Komposisi sampah akan mempengaruhi potensi reduksi sampah rumah tangga di Kecamatan Rungkut.

Komposisi sampah rumah tangga kawasan perumahan yang paling besar adalah sampah dapat dikomposkan, dengan jumlah persentase 67,95\%. Sampah dapat dikomposkan memiliki jumlah komposisi paling besar karena kegiatan rumah tangga setiap hari yang akan menghasilkan sampah dapur atau sampah domestik. Sampah sisa makanan juga memiliki kandungan air yang cukup besar sehingga menyebabkan sampah menjadi berat. Sampah sisa makanan dan sampah kebun masih banyak jumlahnya karena belum banyak masyarakat yang mengolah sampah dapurnya menjadi bentuk lain, misalnya kompos.

Tabel 3.

Komposisi Sampah di Kecamatan Rungkut

\begin{tabular}{lccc}
\hline \hline $\begin{array}{c}\text { Komposisi } \\
\text { Sampah }\end{array}$ & Perumahan & Rusun & Kampung \\
\hline $\begin{array}{l}\text { Dapat } \\
\text { dikomposkan }\end{array}$ & $58,4 \%$ & $61,0 \%$ & $68,0 \%$ \\
Plastik & $17,1 \%$ & $18,7 \%$ & $12,6 \%$ \\
Kertas & $14,9 \%$ & $11,6 \%$ & $10,8 \%$ \\
Logam & $0,3 \%$ & $1,5 \%$ & $1,0 \%$ \\
Kaca & $0,5 \%$ & $0,2 \%$ & $0,3 \%$ \\
Kain & $0,4 \%$ & $0,3 \%$ & $0,4 \%$ \\
Kayu & $4,2 \%$ & $2,8 \%$ & $3,7 \%$ \\
Karet & $0,0 \%$ & $0,0 \%$ & $0,1 \%$ \\
Diapers & $2,5 \%$ & $3,7 \%$ & $2,7 \%$ \\
Lain-lain & $1,4 \%$ & $0,1 \%$ & $0,4 \%$ \\
B3 & $0,1 \%$ & $0,1 \%$ & $0,1 \%$ \\
\hline TOTAL & $\mathbf{1 0 0 , 0 \%}$ & $\mathbf{1 0 0 , 0 \%}$ & $\mathbf{1 0 0 , 0 \%}$ \\
\hline \hline
\end{tabular}

Komposisi sampah rumah susun yang paling besar adalah sampah dapat dikomposkan, dengan jumlah persentase $61 \%$. Sampah dapat dikomposkan memiliki jumlah komposisi paling besar karena kegiatan rumah tangga setiap hari yang akan menghasilkan sampah dapur atau sampah domestik. Hal ini juga dikarenakan masyarakat yang tinggal di kawasan rumah susun berada pada tingkat ekonomi menengah ke bawah, yang akan menyebabkan setiap harinya melakukan kegiatan memasak di rumah dan membuang sampah sisa makanan (sampah dapur). Berbeda dengan masyarakat di perumahan yang tidak sering memasak sehingga persentase sampah sisa makanan tidak sebesar persentase pada kawasan rumah susun.
Komposisi sampah rumah tangga kawasan perkampungan yang paling besar adalah sampah dapat dikomposkan, dengan jumlah persentase $68 \%$. Sampah dapat dikomposkan memiliki jumlah komposisi paling besar karena kegiatan rumah tangga setiap hari yang akan menghasilkan sampah dapur atau sampah domestik. Sama seperti di rumah susun, masyarakat yang tinggal di kawasan perkampungan berekonomi menengah ke bawah, yang akan menyebabkan setiap harinya pasti memasak di rumah dan membuang sampah sisa makanan (sampah dapur). Sehingga sampah dapat dikomposkan di perkampungan memiliki persentase paling besar dibandingkan dengan di perumahan maupun rumah susun.

Sampah plastik menduduki posisi kedua sebagai komposisi terbanyak di sampah kawasan permukiman, sebesar $13 \%$. Kemudian diikuti oleh sampah kertas sebesar 11\%. Sampah plastik di kawasan perkampungan tidak sebanyak di kawasan perumahan. Hal ini disebabkan pada daerah kampung, banyak pemulung yang mengambil sampah-sampah plastik di wadahwadah sampah milik masyarakat. Sehingga sampah plastik yang dihitung dalam komposisi sampah jumlahnya sudah sangat berkurang.

\section{KESIMPULAN}

Berdasarkan penelitian yang telah dilakukan, maka dapat diambil kesimpulan yaitu laju timbulan sampah rumah tangga kawasan perumahan sebesar 0,271 kg/orang.hari. Laju timbulan sampah rumah tangga kawasan rumah susun sebesar $0,282 \mathrm{~kg} /$ orang.hari. Sedangkan laju timbulan sampah rumah tangga kawasan perkampungan sebesar $0,486 \mathrm{~kg} /$ orang.hari. Densitas sampah rumah tangga di Kecamatan Rungkut sebesar $154,93 \mathrm{~kg} / \mathrm{m}^{3}$. Sampah perumahan, rumah susun, dan perkampungan memiliki komposisi paling banyak adalah sampah dapat dikomposkan dikarenakan banyaknya kegiatan rumah tangga sehingga menimbulkan banyaknya sampah dapur atau sisa makanan. Sampah plastik dan kertas merupakan jenis sampah paling banyak setelah sampah dapat dikomposkan.

\section{DAFTAR PUSTAKA}

[1] S. Dhokhikah, Y., Trihadiningrum, Y., Sunaryo, Community participation in household solid waste reduction in Surabaya, Indonesia. Resources, Conservation and Recycling, 2015.

[2] Badan Pusat Statistik Surabaya, Kecamatan Rungkut dalam Angka 2015. BPS Kota Surabaya, 2015.

[3] Pemerintah Kota Surabaya, Peraturan Daerah Kota Surabaya Nomor 72 Tahun 2011 Tentang Pengelolaan Sampah. 2011.

[4] D. K. dan P. K. Surabaya, Dinas Kebersihan dan Pertamanan Kota Surabaya.

[5] R. Isnaini, "Potensi Gas Rumah Kaca Pengelolaan Sampah Domestik di Kecamatan Rungkut Kota Surabaya," Institut Teknologi Sepuluh Nopember.

[6] Badan Standarisasi Nasional, SNI 19-3964-1994 Metode Pengambilan dan Pengukuran Contoh Timbulan dan Komposisi Sampah Perkotaan. 1994.

[7] Badan Standarisasi Nasional, SNI 19-3242-2008 Pengelolaan Sampah di Permukiman. 2008. 